\title{
Antimicrobial Biodegradable Food Packaging Based on Chitosan and Metal/Metal-Oxide Bio-Nanocomposites: A Review
}

\author{
Amin Babaei-Ghazvini ${ }^{1}$ (D), Bishnu Acharya ${ }^{1, *}$ and Darren R. Korber ${ }^{2}$ (D) \\ 1 Department of Chemical and Biological Engineering, University of Saskatchewan, 57 Campus Drive, \\ Saskatoon, SK S7N 5A9, Canada; amin.babaei@usask.ca \\ 2 Department of Food and Bioproduct Sciences, University of Saskatchewan, 51 Campus Drive, \\ Saskatoon, SK S7N 5A8, Canada; darren.korber@usask.ca \\ * Correspondence: bishnu.acharya@usask.ca
}

Citation: Babaei-Ghazvini, A.

Acharya, B.; Korber, D.R

Antimicrobial Biodegradable Food Packaging Based on Chitosan and Metal/Metal-Oxide

Bio-Nanocomposites: A Review.

Polymers 2021, 13, 2790. https://

doi.org/10.3390/polym13162790

Academic Editor: Alexey Iordanskii

Received: 30 July 2021

Accepted: 13 August 2021

Published: 19 August 2021

Publisher's Note: MDPI stays neutral with regard to jurisdictional claims in published maps and institutional affiliations.

Copyright: (c) 2021 by the authors. Licensee MDPI, Basel, Switzerland. This article is an open access article distributed under the terms and conditions of the Creative Commons Attribution (CC BY) license (https:/ / creativecommons.org/licenses/by/ $4.0 /)$.

\begin{abstract}
Finding a practical alternative to decrease the use of conventional polymers in the plastic industry has become an acute concern since industrially-produced plastic waste, mainly conventional food packaging, has become an environmental crisis worldwide. Biodegradable polymers have attracted the attention of researchers as a possible alternative for fossil-based plastics. Chitosan-based packaging materials, in particular, have become a recent focus for the biodegradable food packaging sector due to their biodegradability, non-toxic nature, and antimicrobial properties. Chitosan, obtained from chitin, is the most abundant biopolymer in nature after cellulose. Chitosan is an ideal biomaterial for active packaging as it can be fabricated alone or combined with other polymers as well as metallic antimicrobial particles, either as layers or as coacervates for examination as functional components of active packaging systems. Chitosan-metal/metal oxide bio-nanocomposites have seen growing interest as antimicrobial packaging materials, with several different mechanisms of inhibition speculated to include direct physical interactions or chemical reactions (i.e., the production of reactive oxygen species as well as the increased dissolution of toxic metal cations). The use of chitosan and its metal/metal oxide (i.e., titanium dioxide, zinc oxide, and silver nanoparticles) bio-nanocomposites in packaging applications are the primary focus of discussion in this review.
\end{abstract}

Keywords: chitosan; antimicrobial; metallic nanomaterials; active packaging

\section{Introduction}

Plastic waste, especially classic food packaging, has become an environmental crisis around the world [1,2]. The global demand for biodegradable materials has motivated innovations in the plastics industry to develop polymers obtained from renewable biobased resources [3-5]. Food packaging materials with acceptable mechanical properties [6], barrier properties [7], physical stability, recyclability, and biodegradability [8], as well as functional properties such as antimicrobial [9] and antioxidant activities [10], are highly desirable for food safety and for extending the shelf-life of packaged foods [11]. Currently, the majority of packaging materials produced are still dominated by conventional petroleumbased synthetic polymers since they are relatively cheap and processible with high reliability and durability [12-14]. While immediate changes to the packaging supply chain are incapable of replacing fossil fuel-based plastics at this time, significant advances have been made in the development of environmentally-friendly materials over the past several decades [15-17]. Carbohydrate-based polymers such as starch [18-20], chitosan [21-24], pullulan [25-27], and kefiran [28-31] have been the most considered biopolymers. The protein based polymers (i.e., whey protein [32], soy protein [27], and gelatin [33]) are now providing promising alternates to conventional non-degradable polymers.

Numerous biopolymer modification methods, including cross-linking by using ionizing rays (e.g., high energy UV-irradiation [19,29] and $\gamma$-irradiation [34]), magnetic 
fields [20], chemical reactions [35], the development of bio-nanocomposites [36], and combinations of two biopolymers [37] have also been recently evaluated to improve the functional properties of biopolymers.

Furthermore, the purpose of food packaging materials has more recently evolved from that of simple protection to a system that can provide a single or multiple functional roles in terms of food quality and preservation [38]. These roles could include modifying the inside of the package environment by either absorbing/adsorbing destructive molecules or compounds (such as oxygen and ethylene) [39], or releasing functional ingredients (such as antimicrobials and antioxidants or vitamins) [40]. With the employment of antimicrobial agents in food packaging materials, the growth of microbes could be prevented or delayed, with concurrent improvements in the shelf life of the enclosed foods [41]. In other words, antimicrobial packaging systems could release active agents continuously onto food surfaces, and thus provide extended inhibitory effects against targeted organisms [42]. This approach would improve the effectiveness of antimicrobials with respect to cost and function [21]. Hence, degradable antimicrobial packaging is a novel approach that offers multiple functionalities in a sustainable fashion, thereby addressing the current and future needs of the food sector.

Antimicrobial compounds are generally classified into two main categories: (1) organic and inorganic materials and (2) natural materials. Some examples of organic antimicrobial agents include quaternary ammonium salts, halogenated compounds, organic acids, and phenols; natural materials are based on materials such as chitosan and chitin [22]. Inorganic antimicrobial agents, including metals and metal ions, metal oxide nanoparticles including $\mathrm{TiO}_{2}$ [43], $\mathrm{ZnO}$ [44], silver [45], gold [46], magnesium oxide [47,48] copper [49], copper oxide [50], iron (III) oxide [51], and $\mathrm{CaO}$ [52], have attracted considerable interest in food packaging researches due to their stability, especially under the different conditions imposed in food packaging [53,54].

Chitin is the second most abundant biopolymer on earth after cellulose, and it is found in the exoskeletons of crustaceans (e.g., crabs, shrimps, etc.) and insects [55-57]. Chitosan is a positively-charged, bio-based linear polysaccharide combined of randomly distributed $\beta$-(1-4)-linked D-glucosamine and N-acetyl-D-glucosamine units, and may be produced by the partial deacetylation of chitin. The obtained chitosan is soluble at lower $\mathrm{pH}$ solutions because it has amino groups which are basic and reacts with acidic compounds [58]. There are many amino groups on chitosan's polymer chain, causing the molecule's positive zeta potential. These amino functional groups have $\mathrm{pKa}$ 's around 6.5 , and for this reason, at neural and lower $\mathrm{pH}$ systems, they tend to stay protonated [59]. Commercially-available chitosan is usually reported to have $80 \%$ and even up to $100 \%$ deacetylation [60] with molecular weights ranging from 35 to $800 \mathrm{kDa}$ [61].

The mode of antimicrobial action of chitosan has not yet completely been established, and several "theories" exist. Figure 1 illustrates the chemical structure of the chitosan molecule and possible ways cationic polymers (such as chitosan and metallic nanoparticles) could induce membrane-level (and hence antimicrobial) effects on living cells. The most probable theory for chitosan's lethal effects (Figure 1b,c) is that positively-charged amine groups $\left(\mathrm{NH}_{3}{ }^{+}\right)$of glucosamine interact with the negatively-charged outer membranes of bacteria, causing the formation of pores and resulting in leakage of intracellular components which ultimately causes cell death [62]. In addition to this, other possibilities, such as attachment of chitosan to DNA, could interfere with mRNA replication after chitosan penetrates the cytoplasmic membrane and crosses into the cytoplasm of microorganisms [63]. 


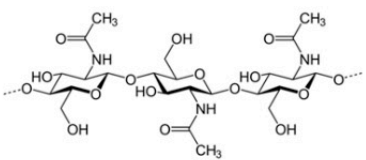

Chitin

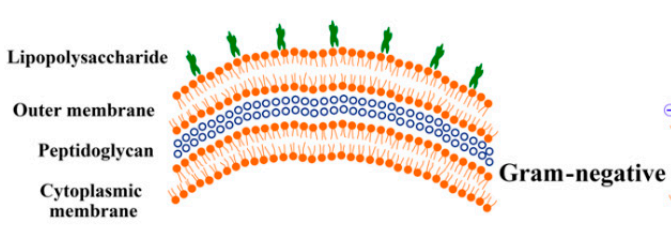

membrane
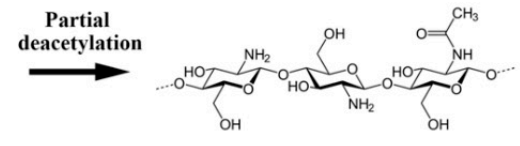

(a)

Chitosan

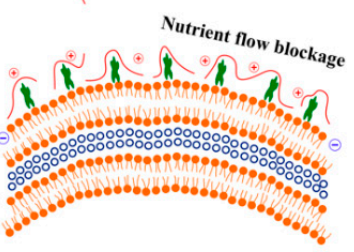

(b)
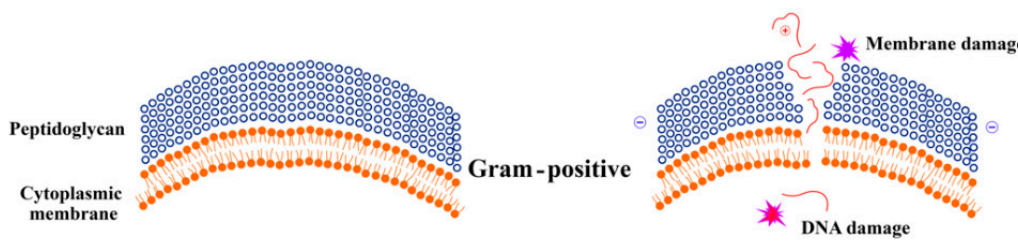

(c)
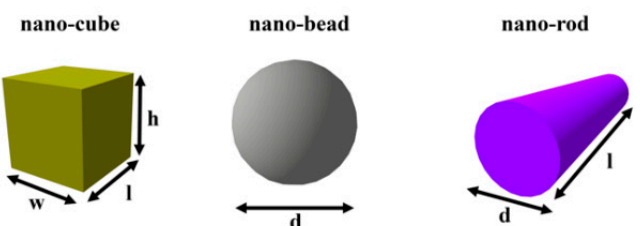

nano-sheet

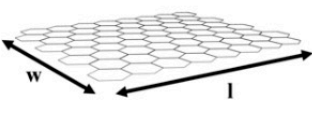

(d)

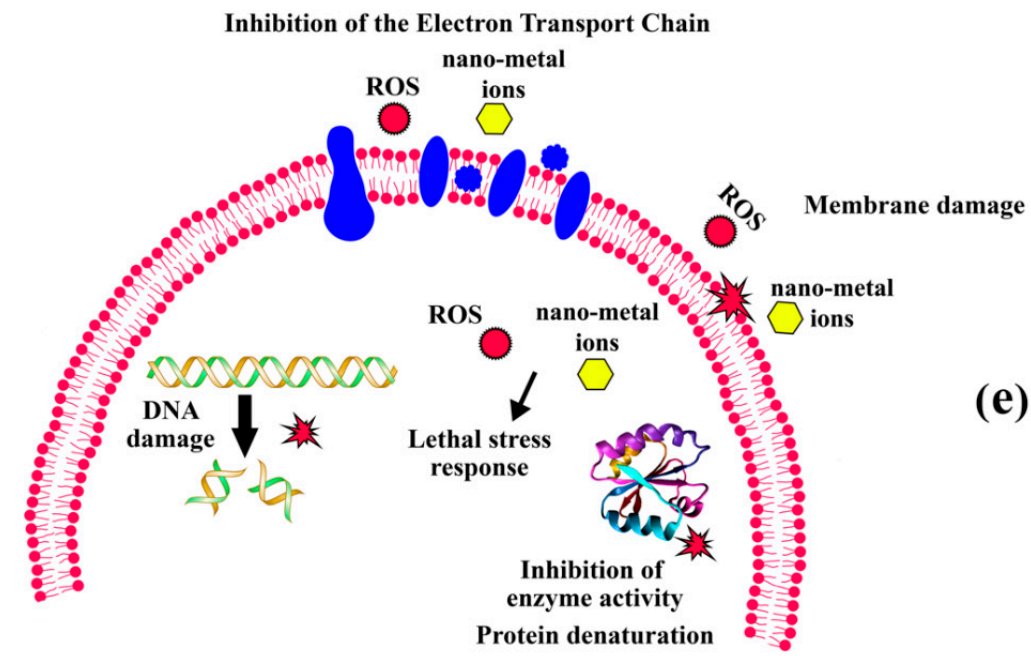

Figure 1. (a) Chitosan production by partial deacetylation of chitin, (b,c) schematic of the Gramnegative and -positive bacteria cell membranes and proposed models for the action of chitosan on cell membrane nutrient flow blockage and damage. The polycationic nature of chitosan causes the release of intercellular components, binding to bacterial DNA (inhibition of mRNA), blocking the nutrient flow and chelation of essential metals (redrawn from Kravanja, Primožič, Knez, and Leitgeb, 2019) [64], (d) schematic of different shapes of metal nanomaterials (reproduced from Cheeseman et al., 2020) [53] and (e) a summary of potential passive antimicrobial mechanisms of metal nanomaterials (not to scale) including physical interactions, release of ions, and production of ROS (adapted from Cheeseman et al., 2020) [53]. 
Regarding possible antimicrobial effects of metallic nanomaterials, several different mechanisms have been proposed and studied, including direct physical interactions or chemical reactions, the production of reactive oxygen species (ROS), and the increased dissolution of toxic metal cations [53,64,65] (Figure 1c-e).

This review will focus on recent major developments in the chitosan-based nanocomposites using titanium dioxide, zinc oxide, and silver nanomaterials. Since metallic nanoparticles have been considered as promising alternatives for conventional antimicrobial agents, their use with chitosan as a cationic bio-based antimicrobial polysaccharide would provide functional features relevant to the biodegradable packaging field.

\section{Comparison of Different Chitosan and Chitosan-Metal Nanocomposites}

\subsection{Chitosan Titanium Dioxide Nanocomposites}

Among the various metal oxide nanomaterials, titanium dioxide $\left(\mathrm{TiO}_{2}\right)$ nanoparticles (TNPs), also known as titanium (IV) oxide, is the natural form of oxidized titanium [65] which are hydrophobic, biocompatible, and have photocatalytic properties, ultraviolet (UV) light absorbance, and excellent antimicrobial properties [65-67]. TNPs are employed in various fields such as electronics, cosmetics, wound healing, environmental pollution repair, and active food packaging [68]. TNPs also have photocatalytic activity, especially under exposure to UV light in the presence of water and oxygen. Under these conditions, ROS can be produced resulting in the production of hydroxyl and superoxide free radicals [69]. These free radicals react with inner cellular macromolecules or the cell membrane phospholipids and thereby produce serious damage of the cell membrane integrity as well as damage to DNA. However, a detailed description of the reaction mechanism of TNPs has not yet been discovered [43,70]. Many academics have studied chitosan/TNP bio-nanocomposites as potential antimicrobial food packaging material. Chitosan/TNP nanocomposites are in the interest of researchers due to the synergic effect of the antimicrobial properties of chitosan and TNP together. TNPs play a photocatalytic role by releasing ROS and chitosan as a cationic polymer leading to the damage of microorganisms' membrane and delaying food spoilage.

Lin et al. (2015) developed chitosan-TNP hybrids with silver nanoparticles (AgNPs) through a photochemical reduction method. They used chitosan as a reducing agent to fabricate the final combined nanocomposite. The nanocomposite concentration for chitosan, TNPs, and AgNPs, were $10 \mathrm{mg} / \mathrm{mL}, 5 \mathrm{mg} / \mathrm{mL}$, and $10 \mathrm{mg} / \mathrm{mL}$, respectively. They then measured the inhibition zones using the disc diffusion method against a nontoxigenic Escherichia coli (E. coli) O157:H7 strain (ATCC 700728) as a representative Gram-negative pathogen surrogate. AgNP-chitosan and TNP-chitosan films were tested as comparator samples against the test cultures. AgNP-chitosan and TNP-chitosan films showed no inhibitory effect (zero diameter of inhibition) under the test conditions. However, TNPAgNP-chitosan nanocomposites showed a significant inhibitory effect with $12.2 \pm 0.7 \mathrm{~mm}$ diameter of inhibition zone, which showed a booster effect of hybrid TNPs and AgNPs with chitosan biopolymer [71].

The antimicrobial effect of chitosan-TNP nanocomposites have been studied against other organisms. For example, Zhang et al. (2017) evaluated chitosan-TNP nanocomposites for their antimicrobial activity under visible light by for food packaging applications. Their chitosan-TNP films possessed efficient antimicrobial activities against four tested strains (i.e., E. coli, Staphylococcus aureus (S. aureus), Candida albicans (C. albicans), and Aspergillus niger (A. niger $)$ ), with $100 \%$ inhibition seen after $12 \mathrm{~h}$. During their antimicrobial tests, chitosan-TNP films $(20 \mathrm{~mm} \times 20 \mathrm{~mm})$ were prepared and then $0.1 \mathrm{~mL}$ of microbial cell suspension $\left(\sim 10^{6} \mathrm{CFU} / \mathrm{mL}\right)$ was spread on the test film samples held under controlled conditions (20 W daylight lamp visible light, $22 \pm 2{ }^{\circ} \mathrm{C}$ temperature, and $50 \pm 5 \%$ humidity). After $4 \mathrm{~h}$, the microbial cells were washed $(5 \times)$ from the films using $2 \mathrm{~mL}$ sterile $0.85 \%$ saline. Then, the number of viable cells remaining were enumerated using the spread plate count method [72]. 
The concentration of antimicrobial agents also plays an essential role in their inhibitory efficacy [73]. Different concentrations of TNPs could have different inhibition effects on microorganisms. Siripatrawan et al. (2018) developed active packaging from a combination of chitosan and TNPs over a range of concentrations $(0,0.25,0.5,1$, and $2 \% w / w)$ and tested the produced composites for application as an ethylene scavenging system as well as an antimicrobial film. Based on tensile strength, water barrier, and ethylene photocatalytic degradation properties, chitosan film containing 1\% TNPs (CT1) was optimal and therefore was selected for further evaluation for antimicrobial effects. They reported that CT1 exhibited antimicrobial activity against Gram-positive (S. aureus) and Gram-negative (E. coli, Salmonella Typhimurium, and Pseudomonas aeruginosa) bacteria and fungi (Aspergillus and Penicillium). Based on their work, chitosan-TNPs nanocomposite films are believed to have more broad application as an active packaging system for various postharvest food applications [74]. Detailed information of their results against different microorganisms is presented in Table 1.

Besides different concentrations of TNPs, mixing them with bio-based antimicrobial extracts offer "green" options for enhancing the antimicrobial properties of the films. Zhang et al. (2019) developed multifunctional food packaging films based on chitosan, TNPs and black plum peel extract (BPPE). They evaluated the antimicrobial activity of the produced films against four food pathogens, including E. coli, S. aureus, Salmonella, and Listeria monocytogenes. They reported that the chitosan-TNPs-BPPE composite film showed the greatest antimicrobial activity compared to the other samples, which probably was due to the synergistic/combined antimicrobial effect of chitosan, $\mathrm{TiO}_{2}$, and $\mathrm{BPPE}$ in the films. Additionally, the author's study confirmed higher antimicrobial activity of their films against Gram-positive than Gram-negative bacteria, which they attributed to differences in the cell membrane structure [75].

In recent work by Hanafy et al. (2021), the authors produced a series of different combinations of thin chitosan-TNPs-oleic acid nanocomposite films formed using casting methods. The antimicrobial effects of the nanocomposite films were investigated by determining zones of inhibition against B. cereus, S. aureus, C. albicans, A. niger, and E. coli. The authors reported an increase in antimicrobial activity against $B$. cereus, $S$. aureus, and $A$. niger as a consequence of increasing the concentration of $\mathrm{TiO}_{2}$ to $15 \mathrm{wt} \%$. A reverse trend for $C$. albicans was reported whereby increasing the amount of TNPs, the films showed less antimicrobial activity against $C$. albicans compared to pure chitosan [76]. Table 1 summarizes the antimicrobial property of chitosan-TNP on different microorganism.

As mentioned before, TNPs exhibit photocatalytic activity, especially under exposure to UV light in the presence of water and oxygen. Some researchers assessed TNPs antimicrobial performance under different lighting conditions. Qu et al. (2019) reported both improved mechanical and antimicrobial properties of a chitosan-zein films following the addition of highly dispersed TNPs. According to their report, the antibacterial effect was evaluated by measuring the diameter of the inhibition zone in dark and UV light (UV irradiation for $30 \mathrm{~min}$ ), respectively. As in some other reports, the antibacterial effect of composite films against $S$. aureus (Gram-positive) was found to be greater than against E. coli or S. enteritidis (Gram-negative). Also, the antibacterial effect of UV light was greater than when incubated under dark conditions. In other words, the inhibition zone of the composite membrane against the three bacteria under UV irradiation was greater than under dark conditions, although no significant difference was found in antibacterial activity among the composite films with different $\mathrm{TiO}_{2}$ contents under dark condition for $24 \mathrm{~h}$. This confirms that the TNPs have higher lethal effect under exposure to UV due to the photocatalytic activity and production of ROS in the medium [77].

Lastly, Lan et al. (2021) developed and studied multifunctional packaging films based on chitosan, nano- $\mathrm{TiO}_{2}$, and red apple pomace (APE). The diameter of inhibition zones was estimated for the different combination of the nanocomposite films against E. coli and S. aureus. Similar to other reports, all of the studied films had more effective 
antimicrobial activities against Gram-positive (S. aureus) compared with Gram-negative bacteria (E. coli) [78].

Table 1. Chitosan-TNP films antimicrobial activity.

\begin{tabular}{|c|c|c|c|c|}
\hline Biopolymer Films & Concentration of TNPs & Tested Microbe & Results & Reference \\
\hline Chitosan-AgNPs-TNPs & $5 \mathrm{mg} / \mathrm{mL}$ & $\begin{array}{l}\text { Escherichia coli } \\
\text { O157:H7 }\end{array}$ & $\begin{array}{c}\text { TNPs: } 7.3 \times 109 \text { CFU mL } \\
\text { Chitosan: } 4.0 \times 109 \mathrm{CFU} \mathrm{mL}^{-1} \\
\text { Chitosan-TNPs: } 5.6 \times 109 \mathrm{CFU} \mathrm{mL}^{-1} \\
\text { Chitosan-TNPs-AgNPs } 3.2 \times 103 \mathrm{CFU} \mathrm{mL}^{-1}\end{array}$ & {$[71]$} \\
\hline Chitosan-TNPs & $\mathrm{N} / \mathrm{A}$ & $\begin{array}{l}\text { E. coli } \\
\text { S. aureus } \\
\text { C. albicans } \\
\text { A. niger }\end{array}$ & $\begin{array}{l}100 \% \text { sterilization in } 12 \mathrm{~h} \text { on all of the tested } \\
\text { microorganisms }\end{array}$ & [72] \\
\hline $\begin{array}{c}\text { Chitosan-TNPs } \\
\text { Chitosan-TNPs + UV treated }\end{array}$ & $1 \%$ & $\begin{array}{c}\text { E. coli } \\
\text { S. aureus } \\
\text { S. Typhimurium } \\
\text { P. aeruginosa } \\
\text { Aspergillus } \\
\text { Penicillium }\end{array}$ & $\begin{array}{c}\text { NUV: } 27 \%, \text { UV: } 53 \% \\
\text { NUV: } 38 \%, \text { UV: } 53 \% \\
\text { NUV: } 11 \%, \text { UV: } 22 \% \\
\text { NUV: } 12 \%, \text { UV: } 15 \% \\
\text { NUV: } 17 \%, \text { UV: } 21 \% \\
\text { NUV: } 5 \%, \text { UV: } 8 \%\end{array}$ & [74] \\
\hline \multirow{5}{*}{ Chitosan-TNPs } & $0 \mathrm{wt} \%$ & $\begin{array}{l}\text { B. cereus } \\
\text { S. aureus } \\
\text { C. albicans } \\
\text { A. niger } \\
\text { E. coli }\end{array}$ & $\begin{array}{l}70.14 \pm 0.02(\%) \\
81.49 \pm 0.20(\%) \\
72.46 \pm 0.08(\%) \\
54.25 \pm 0.02(\%) \\
55.11 \pm 0.03(\%)\end{array}$ & \multirow{6}{*}[76]{} \\
\hline & $\begin{array}{l}2 \mathrm{wt} \% \\
\text { based on chitosan solution }\end{array}$ & $\begin{array}{l}\text { B. cereus } \\
\text { S. aureus } \\
\text { C. albicans } \\
\text { A. niger } \\
\text { E. coli }\end{array}$ & $\begin{array}{l}75.50 \pm 0.15(\%) \\
82.45 \pm 0.04(\%) \\
76.36 \pm 0.31(\%) \\
86.19 \pm 0.25(\%) \\
60.00 \pm 0.04(\%)\end{array}$ & \\
\hline & $\begin{array}{l}5 \mathrm{wt} \% \\
\text { based on chitosan solution }\end{array}$ & $\begin{array}{l}\text { B. cereus } \\
\text { S. aureus } \\
\text { C. albicans } \\
\text { A. niger } \\
\text { E. coli }\end{array}$ & $\begin{array}{l}78.87 \pm 0.05(\%) \\
82.99 \pm 0.18(\%) \\
62.55 \pm 0.07(\%) \\
88.49 \pm 0.27(\%) \\
57.45 \pm 0.11(\%)\end{array}$ & \\
\hline & $\begin{array}{l}10 \mathrm{wt} \% \\
\text { based on chitosan solution }\end{array}$ & $\begin{array}{l}\text { B. cereus } \\
\text { S. aureus } \\
\text { C. albicans } \\
\text { A. niger } \\
\text { E. coli }\end{array}$ & $\begin{array}{l}79.47 \pm 0.01(\%) \\
82.25 \pm 0.14(\%) \\
51.64 \pm 0.06(\%) \\
90.99 \pm 0.21(\%) \\
72.77 \pm 0.15(\%)\end{array}$ & \\
\hline & $\begin{array}{l}15 \mathrm{wt} \% \\
\text { based on chitosan solution }\end{array}$ & $\begin{array}{l}\text { B. cereus } \\
\text { S. aureus } \\
\text { C. albicans } \\
\text { A. niger } \\
\text { E. coli }\end{array}$ & $\begin{array}{l}85.85 \pm 0.21(\%) \\
84.62 \pm 0.18(\%) \\
44.82 \pm 0.09(\%) \\
93.99 \pm 0.29(\%) \\
60.00 \pm 0.25(\%)\end{array}$ & \\
\hline Chitosan-TNPs-oleic acid & $\begin{array}{l}15 \mathrm{wt} \% \\
\text { based on chitosan solution }\end{array}$ & $\begin{array}{l}\text { B. cereus } \\
\text { S. aureus } \\
\text { C. albicans } \\
\text { A. niger } \\
\text { E. coli }\end{array}$ & $\begin{array}{l}50.70 \pm 0.24(\%) \\
82.21 \pm 0.22(\%) \\
71.27 \pm 0.17(\%) \\
95.50 \pm 0.28(\%) \\
42.55 \pm 0.10(\%)\end{array}$ & \\
\hline
\end{tabular}

(\%): Growth Inhibition Percentage, UV and NUV: UV and non-UV treated.

\subsection{Chitosan-Zinc Oxide Nanocomposites}

$\mathrm{ZnO}$ nanoparticles (ZNPs) are low-cost nanoparticles with unique catalytic, electrical (i.e., piezo- and pyro-electric) and optical, photostability, biocompatibility, biodegradability and, most importantly, antimicrobial properties [29]. For example, ZNPs were recently shown to possess high UV absorption, high photocatalytic efficiency, and higher biocompatibility than TNPs [79]. ZNPs in the presence of water and UV light can produce ROS that include hydrogen peroxide $\left(\mathrm{H}_{2} \mathrm{O}_{2}\right)$ and superoxide. A brief description of the possible photochemical reactions that may occur with ZNP are shown in a series of equations (Equations (1)-(4)) and Figure 2. Upon UV irradiation, valence band electrons $\left(\mathrm{e}^{-}\right)$are promoted to the conduction band leaving a hole $\left(\mathrm{h}^{+}\right)$behind (Equation (1)). The holes at 
the ZNPs valence band can oxidize adsorbed water or hydroxide ions to produce hydroxyl radicals (Equation (2)). Electrons in the conduction band on the catalyst surface can reduce molecular oxygen to superoxide anion (Equation (3)). This radical may form organic peroxides or hydrogen peroxide in the presence of organic scavengers (Equation (4)). The hydroxyl radical is a powerful oxidizing agent and attacks organic macromolecules and compounds $[29,80]$.

$$
\begin{gathered}
\mathrm{ZnO}+\mathrm{h} v \rightarrow \mathrm{e}^{-}+\mathrm{h}^{+} \\
\mathrm{h}^{+}+\mathrm{H}_{2} \mathrm{O} \rightarrow \bullet \mathrm{OH}+\mathrm{H}^{+} \\
\mathrm{e}^{-}+\mathrm{O}_{2} \rightarrow \mathrm{O}_{2} \bullet \\
\mathrm{O}_{2} \bullet+\mathrm{HO}_{2} \bullet+\mathrm{H}^{+} \rightarrow \mathrm{H}_{2} \mathrm{O}_{2}+\mathrm{O}_{2}
\end{gathered}
$$

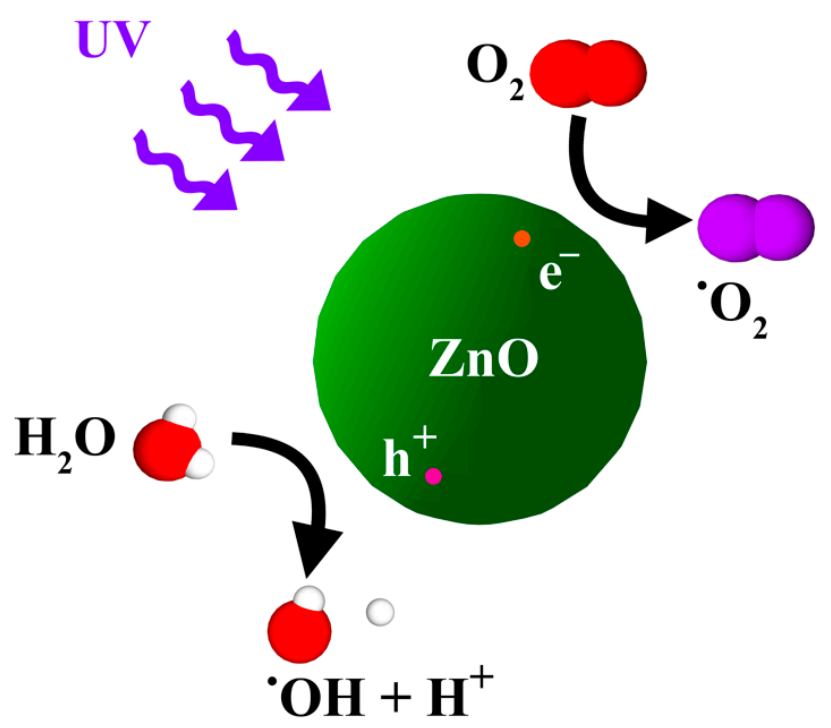

Figure 2. UV-induced photocatalytic activity of $\mathrm{ZnO}$ in the presence of $\mathrm{O}_{2}$ and $\mathrm{H}_{2} \mathrm{O}$ with consequent production of superoxide and hydroxyl radicals.

Fabrication of well-dispersed and proper $\mathrm{ZnO} /$ chitosan nanocomposites is not straightforward due to the fact that chitosan is only soluble in an acidic environment. On the other hand, ZNPs under acidic condition switch into aqueous $\mathrm{Zn}^{2+}$ ions and result in production of chitosan-metal ion complexes and not nanocomposites [81]. Generally, to fabricate chitosan- $\mathrm{ZnO}$ nanocomposites, most researchers follow a two-step process. First, the addition of ZNPs in chitosan low-pH solution is used to produce chitosan- $\mathrm{Zn}$ ion complexes. Following that, the in situ crystallization of $\varepsilon-\mathrm{Zn}(\mathrm{OH})_{2}$ is accomplished using hot alkaline treatment that converts the complexes into chitosan- $\mathrm{ZnO}$ nanocomposites [82].

Youssef et al. (2015) prepared ZNP/AgNP-chitosan nanocomposites for food packaging applications. Accordingly, ZNPs were synthesized using the hydrothermal method, whereas AgNPs were prepared by a direct approach in the presence of chitosan. Furthermore, the authors investigated the effect of acid type (formic or acetic acid) on chitosan films as a dissolving agent. Chitosan-based nanocomposite films yielded good antimicrobial activity using the disc diffusion method against Gram-negative organisms (i.e., E. coli, Salmonella Typhimurium as well as Gram-positive (S. aureus, B. cereus, and L. monocytogenes) bacteria. Chitosan films dissolved in both acids showed significant inhibition zones against all tested strains. The addition of ZNPs and AgNPs increased the nanocomposites' antimicrobial activity. An increase in the concentration of those nanoparticles increased the inhibition zone, with the largest inhibition zone being for a formic acid-dissolved chitosan ZNP nanocomposite, with the following diameters against test strains: E. coli (18 mm), S. Typhimurium (19 mm), S. aureus $(15 \mathrm{~mm})$, B. cereus $(18 \mathrm{~mm})$, and L. monocytogenes $(16 \mathrm{~mm})$ [83]. They did not study the hybrid application of ZNPs and AgNPs, 
which could be an interesting study to discover possible synergic antimicrobial effects of the nanoparticles.

Chitosan-ZNPs (ZNPs with a size of $35-45 \mathrm{~nm}$ ) as an antimicrobial coating on polyethylene (PE) films has been studied by Al-Naamani et al. (2016). By employing an oxygen plasma pretreatment of PE films, the adhesion of the chitosan-ZNP nanocomposite coating layer on the PE surface increased by $2 \%$. The antimicrobial effect of coated (with pure chitosan and chitosan-ZNPs nanocomposite) and un-coated films was evaluated by suspension culture medium (a suspension of test microorganisms on the film specimens). The films were tested against two Gram-negative bacteria, E. coli (ATCC 25922), Salmonella enterica serovar Typhimirium (ATCC 14028), and one Gram-positive bacteria, S. aureus (ATCC 6538). Their results showed that both chitosan-coated PE and chitosan-ZNP coated PE significantly inhibited bacterial growth. PE films did not show any antibacterial effect, as was expected. The chitosan coating had high antimicrobial activity against all tested bacteria with $1.3,1.6$, and $1.4 \log$ reduction against $S$. Typhimurium, E. coli, and S. aureus, respectively. Alternatively, after $24 \mathrm{~h}$ of incubation, the complete growth inhibition resulted from antimicrobial tests using the chitosan-ZNP coatings, which the authors highlighted as having potential for industrial antimicrobial packaging uses [84]. Based on their study, PE coated with chitosan-ZNP nanocomposites offer a promising technique to enhance the antimicrobial properties of the PE films, which is one of the regular petroleum-based plastics used by the food packaging industry. With the reported method, it was possible to inactivate about $99.9 \%$ of pathogenic bacteria cells to increase the shelf life of food products and improve safety.

Different concentrations of ZNPs alone (and in combination with essential oils) have been studied to increase antimicrobial properties of ZNPs film. To increase the physical, mechanical, and antimicrobial properties of the chitosan-based nanocomposites, Sani et al. (2019) developed a chitosan-ZNPs film with Melissa essential oil. Their produced films contained ZNPs $(0,1$, and $3 \%(w / v))$ and Melissa essential oil $(0,0.25$, and $0.5 \%(w / v))$ as reinforcing agents, based on the initial chitosan solution's dry matter concentration, to enhance the functional properties of the films. The disc diffusion method was used to evaluate the antimicrobial properties of the nanocomposites. The prepared film discs (diameter $=15 \mathrm{~mm}$ ) were placed on agar plates containing a lawn of E. coli (ATCC 11775) bacteria. Based on their report, all of the films showed an inhibitory effect that was enhanced by the addition of ZNPs and essential oil. The highest inhibition zone was determined to be the chitosan-ZNP-Melissa essential oil composite preparation, which boosted the antimicrobial effect by the simultaneous use of ZNPs and essential oils [85].

Combining chitosan- $\mathrm{ZnO}$ nanocomposites with other biopolymers has been another approach used to increase the potential packaging properties of ZNP-chitosan bio- nanocomposites. In these studies, chitosan and gelatin nanocomposite hybrid films containing green-synthesized ZNPs were developed, and their properties studied by Kumar et al. (2020). The developed films with $2 \%$ and $4 \%$ ZNPs were again tested for antimicrobial properties using the disc diffusion method; the authors showed that the nanocomposite film had significant antimicrobial activity against $E$. coli. The zones of inhibition of the developed hybrid films containing $1 \%, 2 \%$, and $4 \%$ ZNPs were $10.5,10.5$, and $10.7 \mathrm{~mm}$ in diameter against $E$. coli, respectively [86].

Ahmed et al. (2021) compared nanocomposites films containing chitosan nanoparticles as an organic filler and ZNPs as an inorganic filler to evaluate their different reinforcement method in gelatin/tapioca starch films. They also studied the antimicrobial effect of the films using zones of inhibition against Gram-negative bacteria (E. coli) and Gram-positive bacteria (S. aureus) [87].

In yet another polymer blending approach, Boura-Theodoridou et al. (2020) investigated the performance of chitosan-ZnO nanocomposite film for antimicrobial packaging applications as a function of $\mathrm{NaOH}$ treatment and glycerol/poly (vinyl alcohol) proportions. They reported the successful formation and growth of $\mathrm{ZnO}$ nanoparticles in chitosan-based films following immersion in hot $\mathrm{NaOH}$ solution. Antibacterial activity of the nanocom- 
posites was studied against a panel of organisms that included an E. coli (Gram-negative) isolate, along with B. lactofermentum and C. glutamicum (Gram-positive) strains. Pure chitosan films resulted in almost $100 \%$ inhibition of the growth of all three bacteria. However, they reported that the effect of ZNP content was not clear. They reported a general reduction of antimicrobial efficacy due to the immersion of the films in $\mathrm{NaOH}$ solution which lowers the polycationic character and the solubility of chitosan. In general, the antimicrobial activity of the produced chitosan-ZNPs nanocomposites was greatest against B. lactofermentum, moderate against $E$. coli, and almost absent against C. glutamicum [88]. This suggests the inhibition ability of the pristine chitosan films against $C$. glutamicum and E. coli bacteria before and after growth of ZNPs in the nanocomposite structure is different due to the decrease in polycationic nature of the chitosan caused by the alkaline treatment.

Preparation of multilayer films consisting of chitosan, sodium alginate, and carboxymethyl chitosan-ZnO nanoparticles was studied by Wang et al. (2019). Their study demonstrated distinct antibacterial activities against $S$. aureus and E. coli, and that a significant positive correlation existed between percentage of ZNPs and film antibacterial efficacy [89]. Qui et al. (2019) developed flexible chitosan-ZNP nanocomposite films by in situ precipitation of ZNPs in a chitosan matrix with an alkaline treatment. Accordingly, they reported their chitosan-ZNP films caused 3.4-log and 4.0-log reductions in viable E. coli and S. aureus cells after $0.5 \mathrm{~h}$ exposure, respectively [90]. Akhil Krishnan et al. (2020) produced chitosan-ZNP nanocomposites which the ZNPs were synthesized using orange peel oil using a "green" chemical reduction method. Antibacterial activity of the films investigated by the agar disc diffusion method against $E$. coli, wherein a distinct inhibition of the microorganisms for the ZNP-loaded films was observed. According to the report, the chitosan-ZNP films showed $1.9 \pm 0.1 \mathrm{~cm}$ zone of inhibition, while pristine chitosan film represented a zone of inhibition of $0.9 \pm 0.1 \mathrm{~cm}$ [91]. Yadav et al. (2021) developed food packaging materials based on chitosan and ZNP-loaded gallic acid with improved antibacterial properties against both Gram positive (B. subtilis) and Gram negative (E. coli) bacteria. Reduced antibacterial activity was seen with pure chitosan in comparison to the films dosed with ZNPs and gallic acid in the matrix. It was revealed that increasing ZNPs and gallic acid concentrations from 30 to $70 \mathrm{mg}$ in the film matrix caused significant increases in antibacterial activity [23].

The effect of size of the ZNPs on antimicrobial properties in chitosan matrix were also studied by Zhang et al. (2021). In their work, chitosan nanocomposite films were prepared by incorporating different sizes of zinc oxide particles of $5 \mu \mathrm{m}, 50 \mathrm{~nm}$, and $100 \mathrm{~nm}$. Antimicrobial activity of the films against E. coli and S. aureus revealed that films containing $0.3 \%$ of $50 \mathrm{~nm}$ zinc oxide particles exhibited the best extent of inhibition. Their result showed the size-dependent activity of ZNPs, with smaller ZNPs having enhanced antibacterial activities [92]. A summary of the recent works with more details has been represented in Table 2. 
Table 2. Chitosan-ZNP films antimicrobial activity.

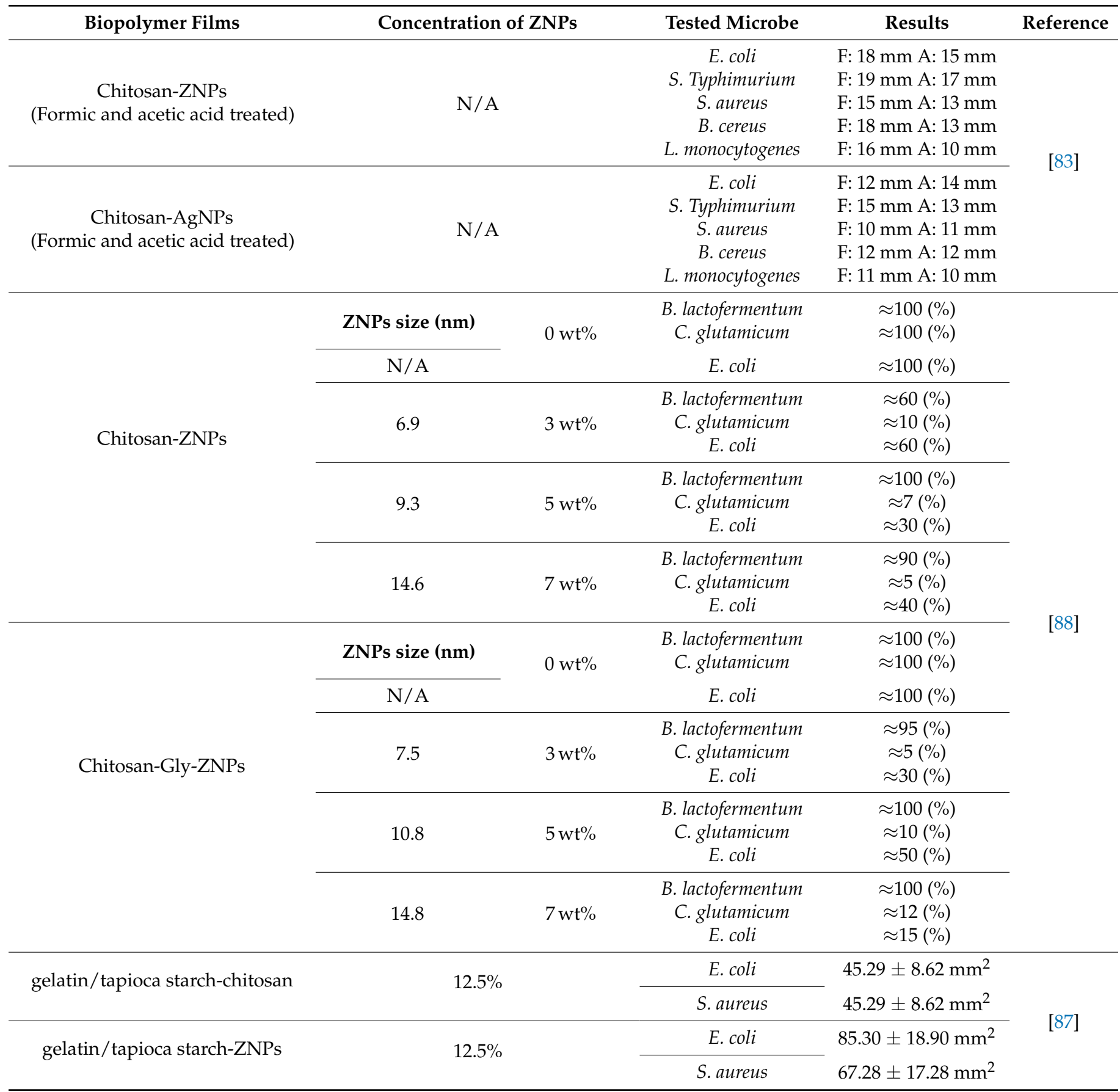

$(\mathrm{mm})$ : Inhibition zone diameter, F and A: formic and acetic acid included, $(\%)$ : Inhibition growth percentage, Gly: Glycerol, $\left(\mathrm{mm}^{2}\right)$ : zone on inhibition (area).

\subsection{Chitosan-Silver Nanocomposites}

Silver nanoparticles (AgNPs) are defined in the literature as compounds containing a large percentage of silver oxide due to the high ratio of silver atoms in the bulk surface. Generally, silver salt and silver-based materials have been well known for their antimicrobial properties since ancient times [93]. Several antimicrobial mechanisms for AgNP activity have been reported, including production and release of $\mathrm{Ag}^{+}$ions, $\mathrm{ROS}$ generation in the outer and inner membrane of microorganisms, cell membrane interference, ribosome destabilization, and mitochondrial and nucleic acids damage (Figure 1e) [94]. The synthesis of Ag-NPs can be achieved by physical, chemical, and biological methods. The biological method for Ag-NPs production could be considered to be an environmentally-friendly 
process, whereas other physical and chemical methods use high amounts of energy and chemical solvents, which are considered toxic, resulting in restrictions on the synthesized nanoparticles potential biomedical and food application $[95,96]$.

Qin et al. (2019) developed chitosan-based active and intelligent food packaging films with incorporated AgNPs (2\%) and purple corn extract. The antibacterial performance of the produced films was studied against E. coli, Salmonella, S. aureus, and L. monocytogenes. Based on their report, chitosan nanocomposites reinforced with AgNPs showed five times higher antimicrobial effects against four foodborne pathogens compared to pure chitosan films [97]. An antioxidant and antibacterial chitosan-tea polyphenols-silver nanoparticle composite films were developed via a novel one-pot method by Zhang and Jiang (2020). Accordingly, AgNPs were produced by reducing $\mathrm{AgNO}_{3}$ using 0.1\% (w/v) tea polyphenol solution. The produced nanocomposites were investigated for their antibacterial performance against S. aureus and E. coli. All of the films with AgNPs presented stronger antibacterial activity against Gram-negative than Gram-positive bacteria [98].

To overcome the drawbacks of pure chitosan films, Cao et al. (2020) developed a new combination of films containing catechol-modified chitosan, AgNPs, and gelatin. The prepared bio-nanocomposites showed exceptional antibacterial behaviors against $S$. aureus and $E$. coli with up to $65 \%$ and $70 \%$ bacterial death percentage, respectively. Their results also confirmed a higher antibacterial behavior against Gram-negative than Gram-positive bacteria [99]. In another study, Kadam et al., (2019), the pH-dependent sustained release of AgNPs synthesized using Nigella sativa extract with a biogenic method from chitosan matrix was demonstrated. The antibacterial performance of the chitosan-based nanocomposite films was investigated against the Gram-positive bacteria $S$. aureus and B. subtilis and Gram-negative bacteria P. aeruginosa and E. coli using a disc diffusion inhibition method. According to their results, composite films demonstrated better antibacterial activity against Gram-negative bacteria compared to the Gram-positive bacteria, which confirms findings seen in similar studies. Additionally, smaller sized AgNPs ( $8 \mathrm{~nm})$ showed greater lethal effects against the studied bacteria [100].

Pandey et al. (2020) developed chitosan-AgNP nanocomposites for food packaging applications. They fabricated the nanocomposite with AgNPs sizes of $80 \pm 11 \mathrm{~nm}$ in chitosan in a polyvinyl alcohol (PVA) blend to form electrospun fibrous composite nanolayers. The antimicrobial activity of the fibrous layer was then analyzed with the agar disc diffusion against E. coli and L. monocytogenes bacteria. The PVA nano-layer did not show any inhibition effect, which was expected. However, the PVA-chitosan and AgNP nanolayers showed a remarkable inhibitory effect against both tested strains. The maximum zone of inhibition (20 mm for E. coli, and $21 \mathrm{~mm}$ for L. monocytogenes) was observed for PVA (70\%)-chitosan (30\%)-AgNP nano-layers, possibly due to the synergistic antimicrobial activity of chitosan and AgNPs. Also, PVA (70\%)-chitosan (30\%) nano-layers without AgNPs showed inhibition zones (16 mm for E. coli, and $15 \mathrm{~mm}$ for L. monocytogenes) due to the electrostatic interaction between the cationic chitosan molecule and negatively charged bacterial cell membranes [101].

A recent study investigated the in vitro antifungal activity of two different chitosan (commercial and shrimp) AgNPs (100 to $250 \mathrm{~nm}$ diameter) nanocomposites [102]. The antifungal evaluation of the films against the phytopathogen Botrytis cinerea was studied since it is considered one of the most important postharvest pathogens in fruit and vegetables. The droplets of conidial solution were inoculated onto the films in a chamber, with a concentration of $10^{6}$ conidia per $\mathrm{mL}$. An inhibition percentage of greater than $97 \%$ were reported by the authors for this study against this fungal organism.

Ghasemzadeh et al. (2021) developed a series of novel full polysaccharide chitosanagarose-AgNPs nanocomposites with in situ reduction of silver ions in the polymeric network. The antimicrobial behavior of the films was evaluated against a panel of bacteria, including $P$. aeruginosa, E. coli, and S. aureus. Chitosan-agarose films did not show antibacterial activity using the disc diffusion method. However, the films containing AgNPs showed significant zones of inhibition against S. aureus, E. coli, and P. aeruginosa [103]. 
More recently, the effect of chitosan-essential oils-AgNP nanocomposite films on the shelf life of strawberries was examined by Shankar et al. (2021), with films showing strong antimicrobial activity against pathogenic bacteria (E. coli, L. monocytogenes, Salmonella) as well as a fungal strain $(A$. niger). The chitosan-AgNP nanocomposites reduced $E$. coli viable counts by 3.4-log CFU/g, L. monocytogenes by 3.0-log CFU/g, Salmonella by 1.4-log CFU/g, and $A$. niger by $0.5-\log$ CFU/g after $16 \mathrm{~h}$ exposure [104].

In an interesting novel food packaging approach, Ramadan et al. (2020) developed cotton fabrics dipped in chitosan solution, dried, and then loaded with silver nanoparticles by an in situ technique. Their research introduced a potential new use of chitosan and metallic nanoparticles for dried food packaging. These antimicrobial fabrics could see use in various packaging processes including the packaging of seeds and powder materials. The inhibitory effects of treated fabrics against Gram negative (P. aeruginosa) and Gram positive (S. aureus) bacteria, fungi (A. niger) and yeast (C. albicans) were investigated. Overall, the fabrics loaded with chitosan and AgNPs showed good antimicrobial properties using a disc diffusion method [105].

\section{Discussion and Conclusions}

Plastic packaging or chemical additives are two primary methods used by the food industry to protect and prevent their products from spoilage. The side effects of these methods on human health are well-known, including direct chemical additives to the food or chemical migration from packaging into the food content [106,107]. Researchers have extensively studied the possible alternative compounds such as polymers and nanomaterials to address these problems. Chitosan and its derivatives seem to be promising biodegradable and biocompatible polymers for food packaging; however, they still suffer from a lack of good packaging properties (e.g., mechanical, thermal, and hydrophobic properties). Hence, the metallic and metal oxide nanomaterials (e.g., $\mathrm{TiO}_{2}, \mathrm{ZnO}$, and $\mathrm{Ag}$ ) were employed to reinforce chitosan-based materials and give them functional properties, including antimicrobial activity. Researchers are still evaluating the respective benefits of these classes of nanomaterials. Based on the current review of the recent reports on using these nanomaterials with chitosan as nanocomposites, the following conclusions of their antimicrobial effects were compiled:

- Chitosan has a great film-forming ability, making this biopolymer a suitable candidate for biodegradable food packaging research. Most of the chitosan-based bionanocomposites have been fabricated through the water-based solution casting method. Due to chitosan's cationic nature, it is soluble in water under acidic conditions (1-2\% acetic or formic acid solution). Chitosan films obtained through this method have a lower final $\mathrm{pH}$ because of the organic acid in their structure, a feature which could cause bolster inhibition of some microorganisms such as coliforms.

- $\mathrm{TiO}_{2}$ nanoparticles have photocatalytic activity, especially under exposure to UV light in the presence of water and oxygen. Under these conditions, ROS can be generated, resulting in production of hydroxyl and superoxide free radicals. These free radicals react with inner cellular macromolecules or the cell membrane phospholipids resulting in severe damage to cell membrane integrity as well as DNA. However, a detailed description of the reaction mechanism of TNPs has not yet been discovered. Reports on $\mathrm{TiO}_{2}$ and chitosan nanocomposites showed more significant inhibition as compared to pure chitosan films due to the additional inhibitory effect of $\mathrm{TiO}_{2}$ nanoparticles. $\mathrm{TiO}_{2}$ nanoparticles show a more significant inhibitory effect under UV exposure comparing white light or dark storage. More antimicrobial activities against Grampositive compared with Gram-negative bacteria with $\mathrm{TiO}_{2}$ nanocomposites have been reported. As mentioned above, the lower $\mathrm{pH}$ has a booster effect on the inhibition of chitosan-based nanocomposites on some microorganisms.

- $\quad$ Like $\mathrm{TiO}_{2}$ nanoparticles, $\mathrm{ZnO}$ nanoparticles have photocatalytic activity but with higher biocompatibility and UV light absorption compared with $\mathrm{TiO}_{2}$. The antimicrobial activity of $\mathrm{ZnO}$ nanoparticles is similar to $\mathrm{TiO}_{2}$ nanoparticles in terms of ROS 
generation. However, the probable generation of hydrogen peroxide $\left(\mathrm{H}_{2} \mathrm{O}_{2}\right)$ during the $\mathrm{ZnO}$ photocatalytic activity under UV-irradiation has been reported. Fabrication of chitosan with $\mathrm{ZnO}$ nanocomposites is different than $\mathrm{TiO}_{2} /$ chitosan nanocomposites because $\mathrm{ZnO}$ nanoparticles may release aqueous $\mathrm{Zn}^{2+}$, which changes the morphology and efficacy of the nanoparticles. Hence, in situ crystallization of $\varepsilon-\mathrm{Zn}(\mathrm{OH})_{2}$ using hot alkaline treatment converts the complexes into chitosan- $\mathrm{ZnO}$ nanocomposites is a common method to fabricate $\mathrm{ZnO}$ chitosan nanocomposites. However, hot alkaline treatment might cause some changes in chitosan polycationic nature, which could be considered a drawback of this method. There has been no report to date on different antimicrobial efficacies against Gram-negative and Gram-positive for chitosan-ZnO nanocomposites. Also, greater inhibitory effects of chitosan- $\mathrm{ZnO}$ and $\mathrm{Ag}$ hybrid nanocomposites has also been reported.

- Silver salt and silver-based materials have been well known for their antimicrobial properties since ancient times. Release of $\mathrm{Ag}^{+}$ions, ROS generation, and cell membrane disruption are the most cited possible antimicrobial mechanisms linked with AgNPs. Works that studied chitosan-AgNPs films reported more potent antibacterial activity against Gram-negative than Gram-positive bacteria, which could be an advantage in combination with other nanoparticles with greater antimicrobial activities against Gram-positive compared. Also, the effect of particle size on the efficacy of the studied nanomaterials showed a smaller range of nanoparticle size offers a more significant inhibition effect against microorganisms. However, the regulations regarding their use in the food industry are still changing and need to be studied more. For example, on a recent announcement from the European Food and Safety Authority (EFSA), the use of $\mathrm{TiO}_{2}$ is no longer considered safe [108].

- Due to the biodegradability, sustainability, and effective film forming properties of chitosan, it has been a promising polysaccharide of interest for researchers in the field of food packaging. The cationic nature of the chitosan shows antimicrobial properties, but not sufficient by itself to be used as the sole antimicrobial agent. Among many metals and metal oxide options, $\mathrm{TiO}_{2}, \mathrm{ZnO}$, and $\mathrm{Ag}$ are ideal nanomaterials to be employed in conjunction with chitosan to enhance the antimicrobial performance of the final films. However, as mentioned above, the cytotoxicity of these materials is still unknown and thus further studies are needed for application in the food industry.

Author Contributions: A.B.-G.: Conceptualization, literature review, writing-original draft, writing-review and editing, visualization. B.A.: conceptualization, source introduction, supervision, funding acquisition, writing-review and editing. D.R.K.: supervision, writing-review \& editing. All authors have read and agreed to the published version of the manuscript.

Funding: The work was supported by Natural Science and Engineering Research Council Discovery Grant program [RGPIN-2016-05728] and Saskatchewan Ministry of Agriculture Research Chair Funds.

Institutional Review Board Statement: Not applicable.

Informed Consent Statement: Not applicable.

Data Availability Statement: No data was reported.

Conflicts of Interest: The authors declare no conflict of interest.

\section{References}

1. Singh, S.; Sharma, S.; Umar, A.; Mehta, S.K.; Bhatti, M.S.; Kansal, S.K. Recycling of waste poly(ethylene terephthalate) bottles by alkaline hydrolysis and recovery of pure nanospindle-shaped terephthalic acid. J. Nanosci. Nanotechnol. 2018, 18, 5804-5809. [CrossRef] [PubMed]

2. Marsh, K.; Bugusu, B. Food packaging—roles, materials, and environmental issues. J. Food Sci. 2007, 72, R39-R55. [CrossRef]

3. Lambert, S.; Wagner, M. Environmental performance of bio-based and biodegradable plastics: The road ahead. Chem. Soc. Rev. 2017, 46, 6855-6871. [CrossRef] [PubMed]

4. Zhu, Y.; Romain, C.; Williams, C.K. Sustainable polymers from renewable resources. Nature 2016, 540, 354-362. [CrossRef] 
5. Pellis, A.; Malinconico, M.; Guarneri, A.; Gardossi, L. Renewable polymers and plastics: Performance beyond the green. N. Biotechnol. 2020, 60, 146-158. [CrossRef] [PubMed]

6. Cazón, P.; Vázquez, M.; Velazquez, G. Cellulose-glycerol-polyvinyl alcohol composite films for food packaging: Evaluation of water adsorption, mechanical properties, light-barrier properties and transparency. Carbohydr. Polym. 2018, 195, 432-443. [CrossRef] [PubMed]

7. Cazón, P.; Vázquez, M. Mechanical and barrier properties of chitosan combined with other components as food packaging film. Environ. Chem. Lett. 2020, 18, 257-267. [CrossRef]

8. Souza, V.G.L.; Fernando, A.L. Nanoparticles in food packaging: Biodegradability and potential migration to food-A review. Food Packag. Shelf Life 2016, 8, 63-70. [CrossRef]

9. Suppakul, P.; Miltz, J.; Sonneveld, K.; Bigger, S.W. Antimicrobial properties of basil and its possible application in food packaging. J. Agric. Food Chem. 2003, 51, 3197-3207. [CrossRef] [PubMed]

10. Bastante, C.C.; Cardoso, L.C.; Serrano, C.M.; de la Ossa, E.J.M. Supercritical impregnation of food packaging films to provide antioxidant properties. J. Supercrit. Fluids 2017, 128, 200-207. [CrossRef]

11. Shankar, S.; Teng, X.; Li, G.; Rhim, J.-W. Preparation, characterization, and antimicrobial activity of gelatin/ZnO nanocomposite films. Food Hydrocoll. 2015, 45, 264-271. [CrossRef]

12. Álvarez-Chávez, C.R.; Edwards, S.; Moure-Eraso, R.; Geiser, K. Sustainability of bio-based plastics: General comparative analysis and recommendations for improvement. J. Clean. Prod. 2012, 23, 47-56. [CrossRef]

13. Kamau-Devers, K.; Miller, S.A. The environmental attributes of wood fiber composites with bio-based or petroleum-based plastics. Int. J. Life Cycle Assess. 2020, 25. [CrossRef]

14. Rhim, J.-W.; Park, H.-M.; Ha, C.-S. Bio-nanocomposites for food packaging applications. Prog. Polym. Sci. 2013, 38, 1629-1652. [CrossRef]

15. Fahmy, H.M.; Eldin, R.E.S.; Serea, E.S.A.; Gomaa, N.M.; AboElmagd, G.M.; Salem, S.A.; Elsayed, Z.A.; Edrees, A.; Shams-Eldin, E.; Shalan, A.E. Advances in nanotechnology and antibacterial properties of biodegradable food packaging materials. RSC Adv. 2020, 10, 20467-20484. [CrossRef]

16. Zubair, M.; Ullah, A. Recent advances in protein derived bionanocomposites for food packaging applications. Crit. Rev. Food Sci. Nutr. 2020, 60, 406-434. [CrossRef] [PubMed]

17. Tang, X.Z.; Kumar, P.; Alavi, S.; Sandeep, K.P. Recent advances in biopolymers and biopolymer-based nanocomposites for food packaging materials. Crit. Rev. Food Sci. Nutr. 2012, 52, 426-442. [CrossRef]

18. Rad, V.F.; Babaei-Ghazvini, A.; Jamali, R.; Shahabi-Ghahfarrokhi, I.; Moradi, A.-R. Digital holographic microscopy for real-time investigation of 3D microstructural dynamics of starch-kefiran -based nanocomposite. Appl. Opt. 2021, 60, 4706-4715. [CrossRef] [PubMed]

19. Shahabi-Ghahfarrokhi, I.; Goudarzi, V.; Babaei-Ghazvini, A. Production of starch based biopolymer by green photochemical reaction at different UV region as a food packaging material: Physicochemical characterization. Int. J. Biol. Macromol. 2018, 122, 201-209. [CrossRef]

20. Babaei-Ghazvini, A.; Cudmore, B.; Dunlop, M.J.; Acharya, B.; Bissessur, R.; Ahmed, M.; Whelan, W.M. Effect of magnetic field alignment of cellulose nanocrystals in starch nanocomposites: Physicochemical and mechanical properties. Carbohydr. Polym. 2020, 247, 116688. [CrossRef]

21. De Azeredo, H.M.C.; Otoni, C.G.; Assis, O.B.G.; Corrêa, D.S.; de Moura, M.R.; Mattoso, L.H.C. Nanoparticles and Antimicrobial Food Packaging. In Nanoparticles and Antimicrobial Food Packaging; Elsevier: Amsterdam, Netherlands, 2018; ISBN 978-0-08100596-5.

22. Wang, H.; Qian, J.; Ding, F. Emerging chitosan-based films for food packaging applications. J. Agric. Food Chem. 2018, 66, 395-413. [CrossRef] [PubMed]

23. Yadav, S.; Mehrotra, G.K.; Dutta, P.K. Chitosan based ZnO nanoparticles loaded gallic-acid films for active food packaging. Food Chem. 2021, 334, 127605. [CrossRef] [PubMed]

24. Wu, J.; Zhong, F.; Li, Y.; Shoemaker, C.F.; Xia, W. Preparation and characterization of pullulan-chitosan and pullulancarboxymethyl chitosan blended films. Food Hydrocoll. 2013, 30, 82-91. [CrossRef]

25. Kraśniewska, K.; Pobiega, K.; Gniewosz, M. Pullulan-biopolymer with potential for use as food packaging. Int. J. Food Eng. 2019, 15, 30. [CrossRef]

26. Luís, Â.; Ramos, A.; Domingues, F. Pullulan Films Containing Rockrose Essential Oil for Potential Food Packaging Applications. Antibiotics 2020, 9, 681. [CrossRef] [PubMed]

27. Rad, F.H.; Sharifan, A.; Khodaiyan, F.; Shahabi, I.; Ghahfarrokhi, I.S. Preparation and Characterization of Pullulan-Soy Protein Concentrate Blended Film Incorporated with Zataria multiflora and Artemisia biennis Essential Oils. Jundishapur J. Nat. Pharm. Prod. 2016, 12.

28. Júnior, L.M.; Vieira, R.P.; Anjos, C.A.R. Kefiran-based films: Fundamental concepts, formulation strategies and properties. Carbohydr. Polym. 2020, 246, 116609. [CrossRef]

29. Shahabi-Ghahfarrokhi, I.; Babaei-Ghazvini, A. Using photo-modification to compatibilize nano-ZnO in development of starchkefiran-ZnO green nanocomposite as food packaging material. Int. J. Biol. Macromol. 2019, 124. [CrossRef] [PubMed]

30. Babaei-Ghazvini, A.; Shahabi-Ghahfarrokhi, I.; Goudarzi, V. Preparation of UV-protective starch/kefiran/ZnO nanocomposite as a packaging film: Characterization. Food Packag. Shelf Life 2018, 16, 103-111. [CrossRef] 
31. Shahabi-Ghahfarrokhi, I.; Babaei-Ghazvini, A. Production of Biodegradable Packaging Material Based on Starch-kefiran-ZnO: Physical and Mechanical Characterization. Iran. J. Biosyst. Eng. 2019, 49, 557-565.

32. Zolfi, M.; Khodaiyan, F.; Mousavi, M.; Hashemi, M. Development and characterization of the kefiran-whey protein isolate-TiO 2 nanocomposite films. Int. J. Biol. Macromol. 2014, 65, 340-345. [CrossRef]

33. Ramos, M.; Valdes, A.; Beltran, A.; Garrigós, M.C. Gelatin-based films and coatings for food packaging applications. Coatings 2016, 6, 41. [CrossRef]

34. Shahabi-Ghahfarrokhi, I.; Khodaiyan, F.; Mousavi, M.; Yousefi, H. Effect of $\gamma$-irradiation on the physical and mechanical properties of kefiran biopolymer film. Int. J. Biol. Macromol. 2015, 74, 343-350. [CrossRef] [PubMed]

35. Reddy, N.; Yang, Y. Citric acid cross-linking of starch films. Food Chem. 2010, 118, 702-711. [CrossRef]

36. Goudarzi, V.; Shahabi-Ghahfarrokhi, I.; Babaei-Ghazvini, A. Preparation of ecofriendly UV-protective food packaging material by starch/TiO2 bio-nanocomposite: Characterization. Int. J. Biol. Macromol. 2017, 95, 306-313. [CrossRef] [PubMed]

37. Motedayen, A.A.; Khodaiyan, F.; Salehi, E.A. Development and characterisation of composite films made of kefiran and starch. Food Chem. 2013, 136, 1231-1238. [CrossRef] [PubMed]

38. Schreiber, S.B.; Bozell, J.J.; Hayes, D.G.; Zivanovic, S. Introduction of primary antioxidant activity to chitosan for application as a multifunctional food packaging material. Food Hydrocoll. 2013, 33, 207-214. [CrossRef]

39. Vermeiren, L.; Heirlings, L.; Devlieghere, F.; Debevere, J. Oxygen, ethylene and other scavengers. Nov. food Packag. Tech. 2003, 22-49.

40. Vasile, C.; Baican, M. Progresses in food packaging, food quality, and safety-controlled-release antioxidant and/or antimicrobial packaging. Molecules 2021, 26, 1263. [CrossRef] [PubMed]

41. Abreu, A.S.; Oliveira, M.; de Sá, A.; Rodrigues, R.M.; Cerqueira, M.A.; Vicente, A.A.; Machado, A. V Antimicrobial nanostructured starch based films for packaging. Carbohydr. Polym. 2015, 129, 127-134. [CrossRef]

42. Malhotra, B.; Keshwani, A.; Kharkwal, H. Antimicrobial food packaging: Potential and pitfalls. Front. Microbiol. 2015,6 , 611. [CrossRef] [PubMed]

43. De Dicastillo, C.L.; Correa, M.G.; Martínez, F.B.; Streitt, C.; Galotto, M.J. Antimicrobial effect of titanium dioxide nanoparticles. In Antimicrobial Resistance-A One Health Perspective; IntechOpen: London, UK, 2020.

44. Padmavathy, N.; Vijayaraghavan, R. Enhanced bioactivity of ZnO nanoparticles-an antimicrobial study. Sci. Technol. Adv. Mater. 2008, 9, 35004. [CrossRef]

45. Rhim, J.W.; Wang, L.F.; Hong, S.I. Preparation and characterization of agar/silver nanoparticles composite films with antimicrobial activity. Food Hydrocoll. 2013, 33, 327-335. [CrossRef]

46. Zhang, W.; Li, Y.; Niu, J.; Chen, Y. Photogeneration of reactive oxygen species on uncoated silver, gold, nickel, and silicon nanoparticles and their antibacterial effects. Langmuir 2013, 29, 4647-4651. [CrossRef] [PubMed]

47. Swaroop, C.; Shukla, M. Development of blown polylactic acid-MgO nanocomposite films for food packaging. Compos. Part A Appl. Sci. Manuf. 2019, 124, 105482. [CrossRef]

48. Nguyen, N.-Y.T.; Grelling, N.; Wetteland, C.L.; Rosario, R.; Liu, H. Antimicrobial activities and mechanisms of magnesium oxide nanoparticles (nMgO) against pathogenic bacteria, yeasts, and biofilms. Sci. Rep. 2018, 8, 1-23. [CrossRef]

49. Alshareef, A.; Laird, K.; Cross, R.B.M. Chemical Synthesis of Copper Nanospheres and Nanocubes and Their Antibacterial Activity against Escherichia coli and Enterococcus sp. Acta Metall. Sin. Engl. Lett. 2017, 30, 29-35. [CrossRef]

50. Mageshwari, K.; Sathyamoorthy, R. Flower-shaped CuO nanostructures: Synthesis, characterization and antimicrobial activity. J. Mater. Sci. Technol. 2013, 29, 909-914. [CrossRef]

51. Anghel, I.; Grumezescu, A.M.; Holban, A.M.; Ficai, A.; Anghel, A.G.; Chifiriuc, M.C. Biohybrid nanostructured iron oxide nanoparticles and Satureja hortensis to prevent fungal biofilm development. Int. J. Mol. Sci. 2013, 14, 18110-18123. [CrossRef]

52. Bang, I.H.; Kim, Y.E.; Min, S.C. Preservation of mandarins using a microbial decontamination system integrating calcium oxide solution washing, modified atmosphere packaging, and dielectric barrier discharge cold plasma treatment. Food Packag. Shelf Life 2021, 29, 100682. [CrossRef]

53. Cheeseman, S.; Christofferson, A.J.; Kariuki, R.; Cozzolino, D.; Daeneke, T.; Crawford, R.J.; Truong, V.K.; Chapman, J.; Elbourne, A. Antimicrobial Metal Nanomaterials: From Passive to Stimuli-Activated Applications. Adv. Sci. 2020, 7, 1902913. [CrossRef] [PubMed]

54. Shahabi-Ghahfarrokhi, I.; Almasi, H.; Babaei-Ghazvini, A. Characteristics of biopolymers from natural resources. In Processing and Development of Polysaccharide-Based Biopolymers for Packaging Applications; Elsevier: Amsterdam, The Netherlands, 2020; pp. 49-95.

55. Kumar, M.N.V.R.; Muzzarelli, R.A.A.; Muzzarelli, C.; Sashiwa, H.; Domb, A.J. Chitosan chemistry and pharmaceutical perspectives. Chem. Rev. 2004, 104, 6017-6084. [CrossRef] [PubMed]

56. Hamed, I.; Özogul, F.; Regenstein, J.M. Industrial applications of crustacean by-products (chitin, chitosan, and chitooligosaccharides): A review. Trends food Sci. Technol. 2016, 48, 40-50. [CrossRef]

57. Watthanaphanit, A.; Supaphol, P.; Tamura, H.; Tokura, S.; Rujiravanit, R. Fabrication, structure, and properties of chitin whisker-reinforced alginate nanocomposite fibers. J. Appl. Polym. Sci. 2008, 110, 890-899. [CrossRef]

58. Sakai, Y.; Hayano, K.; Yoshioka, H.; Yoshioka, H. A novel method of dissolving chitosan in water for industrial application. Polym. J. 2001, 33, 640-642. [CrossRef] 
59. Nurunnabi, M.; Revuri, V.; Huh, K.M.; Lee, Y. Chapter 14 - Polysaccharide based nano/microformulation: An effective and versatile oral drug delivery system. In Micro and Nano Technologies; Andronescu, E., Grumezescu, A.M.B.T.-N., Eds.; Elsevier: Amsterdam, The Netherlands, 2017; pp. 409-433. ISBN 978-0-323-47720-8.

60. Mima, S.; Miya, M.; Iwamoto, R.; Yoshikawa, S. Highly deacetylated chitosan and its properties. J. Appl. Polym. Sci. 1983, 28, 1909-1917. [CrossRef]

61. Luangtana-anan, M.; Opanasopit, P.; Ngawhirunpat, T.; Nunthanid, J.; Sriamornsak, P.; Limmatvapirat, S.; Lim, L.Y. Effect of chitosan salts and molecular weight on a nanoparticulate carrier for therapeutic protein. Pharm. Dev. Technol. 2005, 10, 189-196. [CrossRef] [PubMed]

62. Sudarshan, N.R.; Hoover, D.G.; Knorr, D. Antibacterial action of chitosan. Food Biotechnol. 1992, 6, 257-272. [CrossRef]

63. Kong, M.; Chen, X.G.; Xing, K.; Park, H.J. Antimicrobial properties of chitosan and mode of action: A state of the art review. Int. J. Food Microbiol. 2010, 144, 51-63. [CrossRef] [PubMed]

64. Kravanja, G.; Primožič, M.; Knez, Ž.; Leitgeb, M. Chitosan-based (Nano) materials for novel biomedical applications. Molecules 2019, 24, 1960. [CrossRef]

65. Kominami, H.; Kato, J.; Takada, Y.; Doushi, Y.; Ohtani, B.; Nishimoto, S.; Inoue, M.; Inui, T.; Kera, Y. Novel synthesis of microcrystalline titanium (IV) oxide having high thermal stability and ultra-high photocatalytic activity: Thermal decomposition of titanium (IV) alkoxide in organic solvents. Catal. Lett. 1997, 46, 235-240. [CrossRef]

66. Shaili, T.; Abdorreza, M.N.; Fariborz, N. Functional, thermal, and antimicrobial properties of soluble soybean polysaccharide biocomposites reinforced by nano TiO2. Carbohydr. Polym. 2015, 134, 726-731. [CrossRef]

67. Simonsen, M.E.; Jensen, H.; Li, Z.; Søgaard, E.G. Surface properties and photocatalytic activity of nanocrystalline titania films. J. Photochem. Photobiol. A Chem. 2008, 200, 192-200. [CrossRef]

68. Mesgari, M.; Aalami, A.H.; Sahebkar, A. Antimicrobial activities of chitosan/titanium dioxide composites as a biological nanolayer for food preservation: A review. Int. J. Biol. Macromol. 2021. [CrossRef]

69. Hussain, M.; Bensaid, S.; Geobaldo, F.; Saracco, G.; Russo, N. Photocatalytic Degradation of Ethylene Emitted by Fruits with TiO2 Nanoparticles. Ind. Eng. Chem. Res. 2011, 50, 2536-2543. [CrossRef]

70. Suwalsky, M.; Schneider, C.; Mansilla, H.D.; Kiwi, J. Evidence for the hydration effect at the semiconductor phospholipid-bilayer interface by TiO2 photocatalysis. J. Photochem. Photobiol. B Biol. 2005, 78, 253-258. [CrossRef]

71. Lin, B.; Luo, Y.; Teng, Z.; Zhang, B.; Zhou, B.; Wang, Q. Development of silver/titanium dioxide/chitosan adipate nanocomposite as an antibacterial coating for fruit storage. LWT Food Sci. Technol. 2015, 63, 1206-1213. [CrossRef]

72. Zhang, X.; Xiao, G.; Wang, Y.; Zhao, Y.; Su, H.; Tan, T. Preparation of chitosan-TiO2 composite film with efficient antimicrobial activities under visible light for food packaging applications. Carbohydr. Polym. 2017, 169, 101-107. [CrossRef]

73. Li, J.; Xie, S.; Ahmed, S.; Wang, F.; Gu, Y.; Zhang, C.; Chai, X.; Wu, Y.; Cai, J.; Cheng, G. Antimicrobial activity and resistance: Influencing factors. Front. Pharmacol. 2017, 8, 364. [CrossRef] [PubMed]

74. Siripatrawan, U.; Kaewklin, P. Fabrication and characterization of chitosan-titanium dioxide nanocomposite film as ethylene scavenging and antimicrobial active food packaging. Food Hydrocoll. 2018, 84, 125-134. [CrossRef]

75. Zhang, X.; Liu, Y.; Yong, H.; Qin, Y.; Liu, J.; Liu, J. Development of multifunctional food packaging films based on chitosan, TiO 2 nanoparticles and anthocyanin-rich black plum peel extract. Food Hydrocoll. 2019, 94, 80-92. [CrossRef]

76. Hanafy, M.S.; Desoky, W.M.; Hussein, E.M.; El-Shaer, N.H.; Gomaa, M.; Gamal, A.A.; Esawy, M.A.; Guirguis, O.W. Biological applications study of bio-nanocomposites based on chitosan $/ \mathrm{TiO}_{2}$ nanoparticles polymeric films modified by oleic acid. J. Biomed. Mater. Res. Part A 2021, 109, 232-247. [CrossRef] [PubMed]

77. Qu, L.; Chen, G.; Dong, S.; Huo, Y.; Yin, Z.; Li, S.; Chen, Y. Improved mechanical and antimicrobial properties of zein/chitosan films by adding highly dispersed nano-TiO2. Ind. Crops Prod. 2019, 130, 450-458. [CrossRef]

78. Lan, W.; Wang, S.; Zhang, Z.; Liang, X.; Liu, X.; Zhang, J. Development of red apple pomace extract/chitosan-based films reinforced by TiO2 nanoparticles as a multifunctional packaging material. Int. J. Biol. Macromol. 2021, 168, 105-115. [CrossRef]

79. Sirelkhatim, A.; Mahmud, S.; Seeni, A.; Kaus, N.H.M.; Ann, L.C.; Bakhori, S.K.M.; Hasan, H.; Mohamad, D. Review on zinc oxide nanoparticles: Antibacterial activity and toxicity mechanism. Nano-Micro Lett. 2015, 7, 219-242. [CrossRef] [PubMed]

80. Pera-Titus, M.; García-Molina, V.; Baños, M.A.; Giménez, J.; Esplugas, S. Degradation of chlorophenols by means of advanced oxidation processes: A general review. Appl. Catal. B Environ. 2004, 47, 219-256. [CrossRef]

81. Varma, A.J.; Deshpande, S.V.; Kennedy, J.F. Metal complexation by chitosan and its derivatives: A review. Carbohydr. Polym. 2004, 55, 77-93. [CrossRef]

82. Jia, W.; Dang, S.; Liu, H.; Zhang, Z.; Yu, C.; Liu, X.; Xu, B. Evidence of the formation mechanism of ZnO in aqueous solution. Mater. Lett. 2012, 82, 99-101. [CrossRef]

83. Youssef, A.M.; Abou-Yousef, H.; El-Sayed, S.M.; Kamel, S. Mechanical and antibacterial properties of novel high performance chitosan/nanocomposite films. Int. J. Biol. Macromol. 2015, 76, 25-32. [CrossRef] [PubMed]

84. Al-Naamani, L.; Dobretsov, S.; Dutta, J. Chitosan-zinc oxide nanoparticle composite coating for active food packaging applications. Innov. Food Sci. Emerg. Technol. 2016, 38, 231-237. [CrossRef]

85. Sani, I.K.; Pirsa, S.; Tağı, Ş. Preparation of chitosan/zinc oxide/Melissa officinalis essential oil nano-composite film and evaluation of physical, mechanical and antimicrobial properties by response surface method. Polym. Test. 2019, 79, 106004. [CrossRef]

86. Kumar, S.; Mudai, A.; Roy, B.; Basumatary, I.B.; Mukherjee, A.; Dutta, J. Biodegradable Hybrid Nanocomposite of Chitosan/Gelatin and Green Synthesized Zinc Oxide Nanoparticles for Food Packaging. Foods 2020, 9, 1143. [CrossRef] 
87. Ahmad, A.A.; Sarbon, N.M. A comparative study: Physical, mechanical and antibacterial properties of bio-composite gelatin films as influenced by chitosan and zinc oxide nanoparticles incorporation. Food Biosci. 2021, 43, 101250. [CrossRef]

88. Boura-Theodoridou, O.; Giannakas, A.; Katapodis, P.; Stamatis, H.; Ladavos, A.; Barkoula, N.-M. Performance of ZnO/chitosan nanocomposite films for antimicrobial packaging applications as a function of $\mathrm{NaOH}$ treatment and glycerol/PVOH blending. Food Packag. Shelf Life 2020, 23, 100456. [CrossRef]

89. Wang, H.; Gong, X.; Miao, Y.; Guo, X.; Liu, C.; Fan, Y.-Y.; Zhang, J.; Niu, B.; Li, W. Preparation and characterization of multilayer films composed of chitosan, sodium alginate and carboxymethyl chitosan-ZnO nanoparticles. Food Chem. 2019, 283, 397-403. [CrossRef] [PubMed]

90. Qiu, B.; Xu, X.; Deng, R.; Xia, G.; Shang, X.; Zhou, P. Construction of chitosan/ZnO nanocomposite film by in situ precipitation. Int. J. Biol. Macromol. 2019, 122, 82-87. [CrossRef] [PubMed]

91. Krishnan, R.A.; Mhatre, O.; Sheth, J.; Prabhu, S.; Jain, R.; Dandekar, P. Synthesis of zinc oxide nanostructures using orange peel oil for fabricating chitosan-zinc oxide composite films and their antibacterial activity. J. Polym. Res. 2020, 27, 206. [CrossRef]

92. Zhang, X.; Zhang, Z.; Wu, W.; Yang, J.; Yang, Q. Preparation and characterization of chitosan/Nano-ZnO composite film with antimicrobial activity. Bioprocess Biosyst. Eng. 2021. [CrossRef] [PubMed]

93. Nandana, C.N.; Christeena, M.; Bharathi, D. Synthesis and characterization of chitosan/silver nanocomposite using rutin for antibacterial, antioxidant and photocatalytic applications. J. Clust. Sci. 2021, 1-11.

94. Alavi, M.; Kennedy, J.F. Recent advances of fabricated and modified Ag, Cu, CuO and $\mathrm{ZnO}$ nanoparticles by herbal secondary metabolites, cellulose and pectin polymers for antimicrobial applications. Cellulose 2021, 1-14.

95. Abdallah, O.M.; EL-Baghdady, K.Z.; Khalil, M.M.H.; El Borhamy, M.I.; Meligi, G.A. Antibacterial, antibiofilm and cytotoxic activities of biogenic polyvinyl alcohol-silver and chitosan-silver nanocomposites. J. Polym. Res. 2020, 27, 1-9. [CrossRef]

96. Tripathi, R.M.; Pudake, R.N.; Shrivastav, B.R.; Shrivastav, A. Antibacterial activity of poly (vinyl alcohol)—biogenic silver nanocomposite film for food packaging material. Adv. Nat. Sci. Nanosci. Nanotechnol. 2018, 9, 25020. [CrossRef]

97. Qin, Y.; Liu, Y.; Yuan, L.; Yong, H.; Liu, J. Preparation and characterization of antioxidant, antimicrobial and pH-sensitive films based on chitosan, silver nanoparticles and purple corn extract. Food Hydrocoll. 2019, 96, 102-111. [CrossRef]

98. Zhang, W.; Jiang, W. Antioxidant and antibacterial chitosan film with tea polyphenols-mediated green synthesis silver nanoparticle via a novel one-pot method. Int. J. Biol. Macromol. 2020, 155, 1252-1261. [CrossRef] [PubMed]

99. Cao, W.; Yan, J.; Liu, C.; Zhang, J.; Wang, H.; Gao, X.; Yan, H.; Niu, B.; Li, W. Preparation and characterization of catechol-grafted chitosan/gelatin/modified chitosan-AgNP blend films. Carbohydr. Polym. 2020, 247, 116643. [CrossRef]

100. Kadam, D.; Momin, B.; Palamthodi, S.; Lele, S.S. Physicochemical and functional properties of chitosan-based nano-composite films incorporated with biogenic silver nanoparticles. Carbohydr. Polym. 2019, 211, 124-132. [CrossRef] [PubMed]

101. Pandey, V.K.; Upadhyay, S.N.; Niranjan, K.; Mishra, P.K. Antimicrobial biodegradable chitosan-based composite Nano-layers for food packaging. Int. J. Biol. Macromol. 2020, 157, 212-219. [CrossRef]

102. Ortiz-Duarte, G.; Martínez-Hernández, G.B.; Casillas-Peñuelas, R.; Pérez-Cabrera, L.E. Evaluation of Biopolymer Films Containing Silver-Chitosan Nanocomposites. Food Bioprocess Technol. 2021, 14, 492-504. [CrossRef]

103. Ghasemzadeh, H.; Afraz, S.; Moradi, M.; Hassanpour, S. Antimicrobial chitosan-agarose full polysaccharide silver nanocomposite films. Int. J. Biol. Macromol. 2021, 179, 532-541. [CrossRef]

104. Shankar, S.; Khodaei, D.; Lacroix, M. Effect of chitosan/essential oils/silver nanoparticles composite films packaging and gamma irradiation on shelf life of strawberries. Food Hydrocoll. 2021, 117, 106750. [CrossRef]

105. Ramadan, M.A.; Sharawy, S.; Elbisi, M.K.; Ghosal, K. Eco-friendly Packaging Composite Fabrics based on in situ synthesized Silver nanoparticles (AgNPs) \& treatment with Chitosan and/or Date seed extract. Nano-Structures Nano-Objects 2020, $22,100425$. [CrossRef]

106. Flores, M.; Toldrá, F. Chemistry, safety, and regulatory considerations in the use of nitrite and nitrate from natural origin in meat products. Meat Sci. 2020, 108272. [CrossRef]

107. Bhunia, K.; Sablani, S.S.; Tang, J.; Rasco, B. Migration of chemical compounds from packaging polymers during microwave, conventional heat treatment, and storage. Compr. Rev. Food Sci. Food Saf. 2013, 12, 523-545. [CrossRef]

108. EFSA TiO2 Ban. Available online: https://www.foodnavigator.com/Article/2021/05/06/Titanium-dioxide-EFSA-says-E171-nolonger-considered-safe (accessed on 6 May 2021). 